\title{
Balneotherapy treatment for patients suffering from low back pain
}

\author{
Pablo Cheza López ${ }^{1}$
}

Corresponding author: Pablo Cheza López, E-mail: pcheza 5@hotmail.com,

\begin{abstract}
Nowadays, a significant number of people experience low back pain during his lifetime. The causes are not clear at all, but several studies attribute this musculoskeletal disease to economical and psychosocial factors. Among all the treatments proposed, this study focuses in balneotherapy. The search in Medline Database through PubMed, PEDro and Cochrane Library, has yielded some interesting results. Consulted bibliography show that balneotherapy may be effective in the treatment of low back pain, but there are not so many correctly-designed studies to affirm this fact with evidence.
\end{abstract}

Key words: balneotherapy, low back pain, medicinal water, mud therapy,

\section{Introduction}

Low back pain is an extremely common problem that most people experience at least once in their life (1). The prevalence of suffering low back pain increases linearly from the third decade of life on, until the 60 years of age, being more prevalent in women (2).

Leaving aside serious medical or psychological conditions and according to International Statistical Classification of Diseases and Related Health Problems (ICD), there are different categories: low back pain, lumbago, lumbosacral segmental/somatic dysfunction, low back strain, spinal instabilities, flatback syndrome, lumbago due to displacement of intervertebral disc, lumbago with sciatica (3).

The Orthopaedic Section of the American Physical Therapy Association (APTA) affirms that current literature does not support a definitive cause for initial episodes of low back pain. Risk factors are multifactorial, population specific, and only weakly associated with the development of low back pain (3). Despite this, several studies attribute low back pain to economical factors as income levels per capita, psychosocial factors like work-family imbalance, exposure to hostile work, job insecurity, long work hours and certain occupation groups $(4,5,6,7)$. The 6 European Working Conditions Survey showed that the percentage of workers who feel some pain derived from the postures or efforts made at work was $77,5 \%$. The main location of pain was low back with $44,9 \%$ of all participants, followed by neck pain with 34,3\%. The survey also affirmed that an important percentage of workers of transportation and storage sector $(53,7 \%)$ construction sector $(52,5 \%)$ and health and social activities $(52,2 \%)$ referred low back pain (8). Low back pain has some consequences, as it is associated with short sleep duration and poor sleep quality (9).

It is the number one cause of dissability (10). Although people don't die from low back pain, the morbidity toll is enormous from both personal and societal perspectives. It is reported by more patients and has a higher impact in the workforce, as well as financially, than any other musculoskeletal disorder and most other clinical conditions (11). The trend to suffer low back pain is upward. Freburger, et al demonstrated an increase in chronic low back pain from $3.9 \%$ in 1992 to $10.2 \%$ in 2006 in a telephone survey of North Carolina households (12).

Because non-specific low back pain does not have a known pathoanatomical cause, treatment focuses on reducing pain and its consequences (13). The treatment includes pharmacological and nonpharmacological therapies (psychological therapies, multidisciplinary rehabilitation, spinal manipulation, acupuncture, massage, exercise and related therapies, and various physical modalities) (14). 
Balneotherapy is the treatment of disease by bathing in thermal spring water (15). It is based on the buoyancy, physical properties, temperature, and chemical effects of mineral water (16). Mud is a heated slurry, which is the result of the combination of solid material (mainly clay) and mineral water, used for external application after an adequate maturation period, at a temperature between $45^{\circ} \mathrm{C}$ and $50^{\circ} \mathrm{C}(17)$. The aim of this review is to analyze if balneotherapy is an effective treatment for low back pain.

\section{Methods}

The search was carried out in different databases. The search strategy varied according to each database:

Medline Database through PubMed: The search was made the 30 of January 2019.

1. Terms search: "balneotherapy", "low back pain". 53 results were found.

2. The publication dates were changed to 10 years, and the search was restricted to human species. 25 results were found.

3. The abstracts were read to select the potentially interesting articles.

4. Another search was made with the terms: "mud", "low back pain". 13 results were found.

5. The publication dates were changed to 10 years, and the search was restricted to human species. 7 results were found.

6. They were selected the articles according to this study.

PEDro: The search was made the 5 of February 2019.

1. Advanced search: "Balneotherapy low back pain"

2. Therapy: hydrotherapy, balneotherapy

3. Body part: lumbar spine, sacro-iliac joint or pelvis

4. Published since: 2009

5. 5 records were found. The abstracts were read to select the interesting results.

6. Advanced search: "Mud low back pain"

7. Therapy: hydrotherapy, balneotherapy

8. Body part: lumbar spine, sacro-iliac joint or pelvis

9. Published since: 2009

10. 2 records were found. The abstracts were read to select the interesting ones.
Cochrane Library: The search was made the 5 of February 2019

1. Advanced search with the terms: "Balneotherapy" AND "low back pain"

2. The search was limited to the last ten years.

3. 10 essays were found. The abstract determined which ones were chords to the study.

4. Advanced search with the terms: "Mud therapy" AND "low back pain"

5. The search was limited to the last ten years.

Only 2 essays were found. The reading of the abstract concluded in the selection of the appropriate.

\section{Results}

Table 1. Effectiveness of balneotherapy in low back pain.

\section{Discussion}

Based on the results of the table, it can be affirmed that balneotherapy alleviates pain in patients suffering from low back pain, as all the essays found that there was an improve in the symptoms. However, more than a half of the studies $(53,33 \%)$, did not find statistically evidence. It is difficult to extract statistically significant results from each study, and also comparing the studies between them. According to Morer et al. 2017; the current randomized clinical trials are very heterogeneous (23). Roques \& Queneau, 2016; named three causes of that poor results: limited enrolment of patients, an insufficient duration of follow-up, and inhomogeneity of treatments (20).

Each study was made in different places, so the characteristics of mineral water were different too, according to the temperature and the mineralization. Furthermore, as this review shows at introduction, there are several categories of low back pain, so it is complicated to talk about it as a unique disease. Results can not be significant taking into account the heterogeneity between the essays. Well-designed studies are necessary to extract more acute information of the effect of mineral water in low back pain patients $(20,23,26,27)$. This study can not prove that balneotherapy is an effective treatment for low back pain, but it shows that it is necessary to continue investigating the effects of mineral water, and encourages researchers to carry out. 
Table 1. Effectiveness of balneotherapy in low back pain.

\begin{tabular}{|c|c|c|c|c|}
\hline Tittle & Authors & Year & Material and methods & Results \\
\hline $\begin{array}{l}\text { Dead Sea mud packs } \\
\text { for chronic low back } \\
\text { pain (18) }\end{array}$ & $\begin{array}{l}\text { Abu-Shakra, M., } \\
\text { Mayer, A., Friger, } \\
\text { M., Harari, M. }\end{array}$ & 2014 & $\begin{array}{c}46 \text { consecutive patients } \\
\text { suffering from CLBP } \\
\text { randomized into two groups: } \\
\text { one group was treated with } \\
\text { mineral-rich mud compresses, } \\
\text { and the other with mineral- } \\
\text { depleted compresses. Mud } \\
\text { compresses were applied five } \\
\text { times a week for } 3 \text { consecutive } \\
\text { weeks. }\end{array}$ & $\begin{array}{l}\text { Pain severity was reduced in patients } \\
\text { treated with mineral-rich mud } \\
\text { compresses compared with those treated } \\
\text { with mineral-depleted compresses. } \\
\text { Whether this modest effect is the result } \\
\text { of a "true" mud effect or other causes } \\
\text { can not be determined in this study }\end{array}$ \\
\hline $\begin{array}{c}\text { Effect of thermal } \\
\text { water and adjunctive } \\
\text { electrotherapy on } \\
\text { chronic low back } \\
\text { pain: a double-blind, } \\
\text { randomized, follow- } \\
\text { up study (19) }\end{array}$ & $\begin{array}{l}\text { Kulisch, A., Bender, } \\
\text { T., Németh, A., } \\
\text { Szekeres, L. }\end{array}$ & 2009 & $\begin{array}{l}71 \text { patients who underwent } 20- \\
\text { minute daily treatment } \\
\text { sessions with medicinal water } \\
\text { or with tap water, both at a } \\
\text { temperature of } 34 \text { degrees } \mathrm{C} \text {, } \\
\text { on } 21 \text { occasions. Both groups } \\
\text { underwent additional } \\
\text { adjunctive electrotherapy. The } \\
\text { treatment was carried put } \\
\text { during } 15 \text { weeks }\end{array}$ & $\begin{array}{l}\text { In the group treated with thermal water, } \\
\text { improvement occurred earlier, lasted } \\
\text { longer and was statistically significant }\end{array}$ \\
\hline $\begin{array}{l}\text { [SPA therapy for } \\
\text { pain of patients with } \\
\text { chronic low back } \\
\text { pain, knee osteo- } \\
\text { arthritis and } \\
\text { fibromyalgia] (20) }\end{array}$ & $\begin{array}{l}\text { Roques, CF., } \\
\text { Queneau, P. }\end{array}$ & 2016 & $\begin{array}{l}10 \text { randomized controlled } \\
\text { trials, } 1192 \text { patients }\end{array}$ & $\begin{array}{l}\text { Pain was significantly improved by } \\
\text { balneotherapy and significantly better } \\
\text { improved than by control treatments. } \\
\text { However several methodological biases } \\
\text { were observed in many trials, mainly a } \\
\text { lack of statistical power due to a limited } \\
\text { enrolment of patients, an insufficient } \\
\text { duration of follow-up, an inhomogeneity } \\
\text { of treatments. }\end{array}$ \\
\hline $\begin{array}{l}\text { The effectiveness of } \\
\text { balneotherapy in } \\
\text { chronic low back } \\
\text { pain (21) }\end{array}$ & $\begin{array}{l}\text { Onat, ŞŞ., Taşoğlu, } \\
\text { Ö., Güneri, FD., } \\
\text { Özişler, Z., Safer, } \\
\text { VB., Özgirgin, N. }\end{array}$ & 2014 & $\begin{array}{l}81 \text { patients with LBP were } \\
\text { followed up in two groups for } \\
\text { a } 3 \text {-week treatment program. } \\
\text { Patients in group I ( } \mathrm{n}=44) \\
\text { were treated with physical } \\
\text { therapy alone. Patients in } \\
\text { group II }(\mathrm{n}=37) \text { were treated } \\
\text { with balneotherapy in addition } \\
\text { to the same physical therapy } \\
\text { protocol in group I. Patients in } \\
\text { both groups were given a } \\
\text { home-based standardized } \\
\text { exercise program }\end{array}$ & $\begin{array}{l}\text { All of the measured parameters } \\
\text { improved in both groups. However, } \\
\text { improvements in pain, functionality, and } \\
\text { quality of life scores were found to be } \\
\text { superior in the balneotherapy plus } \\
\text { physical therapy group. For the patients } \\
\text { with CLBP, balneotherapy plus physical } \\
\text { therapy is more effective, compared to } \\
\text { physical therapy alone }\end{array}$ \\
\hline $\begin{array}{l}\text { The effects of the } \\
\text { calcium-magnesium- } \\
\text { bicarbonate content } \\
\text { in thermal mineral } \\
\text { water on chronic low } \\
\text { back pain: a } \\
\text { randomized, } \\
\text { controlled follow-up } \\
\text { study (22) }\end{array}$ & $\begin{array}{l}\text { Gáti, T., Tefner, } \\
\text { IK., Kovács, L., } \\
\text { Hodosi, K., Bender, } \\
\text { T. }\end{array}$ & 2018 & $\begin{array}{l}105 \text { patients suffering from } \\
\text { CLBP. The control group } \\
(\mathrm{n}=53) \text { received the } \\
\text { traditional musculoskeletal } \\
\text { pain killer treatment, while the } \\
\text { target group }(\mathrm{n}=52) \text { attended } \\
\text { thermal mineral water } \\
\text { treatment for } 3 \text { weeks for } 15 \\
\text { occasions. }\end{array}$ & $\begin{array}{l}\text { All of the investigated parameters } \\
\text { improved significantly in the target } \\
\text { group by the end of the treatment, and } \\
\text { this improvement was persistent during } \\
\text { the follow-up period There were no } \\
\text { significant changes in the measured } \\
\text { parameters in the control group. Based } \\
\text { on the results, balneotherapy might have } \\
\text { favorable impact on the clinical } \\
\text { parameters and quality of life of patients } \\
\text { suffering from CLBP }\end{array}$ \\
\hline
\end{tabular}


The role of mineral elements and other chemical compounds used in balneology: data from doubleblind randomized clinical trials (23)
Morer, C., Roques, CF., Françon, A., Forestier, R., Maraver, F.
2017

27 double-blind randomized clinical trials. A total of 1118 patients with rheumatological and other musculoskeletal diseases were evaluated in these studies: 147 for CLBP. 82 of these participants were assigned to the experimental group. They were treated with mineral water baths and/or $\mathrm{mud} /$ peloid (with or without other forms of treatment, like physical therapy, exercise...). The rest were allocated to the control group; they received mainly tap water and/or "nonmineral" mud/peloid treatments.
Comparison of the effects of land-based and water-based therapeutic exercises on the range of motion and physical disability in patients with chronic lowback pain: singleblinded randomized study (24)

\section{Evidence-based} hydro- and balneotherapy in

Hungary--a systematic review and meta-analysis (25)
Nemcić, T.,

Budisin, V.,

Vrabec-Matković,

D., Grazio, S.
2013

72 patients hospitalized for inpatient treatment in a special rehabilitation hospital, 36 patients performed a 3-week standardized program of group water-based exercises and the other 36 performed a program of group land-based exercises. All patients were also treated with electro analgesic therapy and underwater massage.
Mineral water or mud treatments had better and longer improvements in pain, function, quality of life, clinical parameters, and others in some rheumatological diseases.

Internal validity and other limitations of the study's methodology impede causal relation of spa therapy on these improvements. Existing research is not sufficiently strong to draw firm conclusions

In the sample of patients with chronic

low back pain, exercise treatment improved lumbar motion and decreased the level of physical disability.

However, comparison of land-based exercises and water-based exercises in thermal mineral water did not demonstrate any significantly different result.

Bender, T., Bálint, G., Prohászka, Z., Géher, P., Tefner, IK.
Systematic review and metaanalysis of clinical trials. 122 studies identified in different databases include 18 clinical trials. 5 of these evaluated the effect of hydro- and balneotherapy on chronic low back pain

\begin{tabular}{|c|c|c|c|}
\hline $\begin{array}{l}\text { Aquatic exercise \& } \\
\text { balneotherapy in } \\
\text { musculoskeletal } \\
\text { conditions (26) }\end{array}$ & $\begin{array}{c}\text { Verhagen, AP., } \\
\text { Cardoso, JR., } \\
\text { Bierma-Zeinstra, } \\
\text { SM. }\end{array}$ & 2012 & A review of 30 years \\
\hline $\begin{array}{l}\text { Balneotherapy for } \\
\text { chronic low back } \\
\text { pain: a randomized, } \\
\text { controlled study }(27)\end{array}$ & $\begin{array}{c}\text { Kesiktas, N., } \\
\text { Karakas, S., Gun, } \\
\text { K., Gun, N., Murat, } \\
\text { S., Uludag, M. }\end{array}$ & 2012 & $\begin{array}{l}60 \text { patients with CLBP were } \\
\text { randomly divided into two } \\
\text { groups. Physical modalities } \\
\text { plus exercise were applied to } \\
\text { group 1, and group } 2 \text { was } \\
\text { received balneotherapy plus } \\
\text { exercise for } 10 \text { sessions }\end{array}$ \\
\hline
\end{tabular}

Balneotherapy with Hungarian thermalmineral waters is an effective remedy for lower back pain

Exercises in general, and specifically aquatic exercises, are beneficial for reducing pain and disability in many musculoskeletal conditions demonstrating small to moderate effect. Balneotherapy might be beneficial, but the evidence is yet insufficient to make a definitive statement about its use

Balneotherapy combined with exercise therapy had advantages than therapy with physical modalities plus exercise in improving quality of life and flexibility of patients with CLBP 


\begin{tabular}{|c|c|c|c|c|}
\hline $\begin{array}{l}\text { The effect of spa } \\
\text { therapy in chronic } \\
\text { low back pain: a } \\
\text { randomized } \\
\text { controlled, single- } \\
\text { blind, follow-up } \\
\text { study (28) }\end{array}$ & $\begin{array}{l}\text { Tefner, IK., } \\
\text { Németh, A., } \\
\text { Lászlófi, A., Kis, T., } \\
\text { Gyetvai, G., } \\
\text { Bender, T. }\end{array}$ & 2012 & $\begin{array}{l}60 \text { patients with CLBP pain } \\
\text { were randomized into two } \\
\text { groups. The treatment group } \\
\text { received balneotherapy with } \\
\text { thermal-mineral water, and the } \\
\text { control group bathed in tap } \\
\text { water }\end{array}$ & $\begin{array}{l}\text { The study demonstrated the beneficial } \\
\text { effect of balneotherapy with thermal } \\
\text { mineral versus tap water on clinical } \\
\text { parameters, along with improvements in } \\
\text { quality of life }\end{array}$ \\
\hline $\begin{array}{c}\text { Additional } \\
\text { therapeutic effect of } \\
\text { balneotherapy in low } \\
\text { back pain (29) }\end{array}$ & $\begin{array}{l}\text { Dogan, M., Sahin, } \\
\text { O., Elden, H., } \\
\text { Hayta, E., } \\
\text { Kaptanoglu, E. }\end{array}$ & 2011 & $\begin{array}{l}60 \text { patients with lumbar } \\
\text { spondylosis were included in } \\
\text { the study. In Group 1, patients } \\
\text { received both balneotherapy } \\
\text { and physiotherapy and in } \\
\text { Group 2, patients received } \\
\text { only physiotherapy for } 3 \\
\text { weeks }\end{array}$ & $\begin{array}{l}\text { There was no statistically significant } \\
\text { difference between the two groups. All } \\
\text { clinical parameters significantly } \\
\text { improved patients in both of the groups. } \\
\text { The study reiterated that besides } \\
\text { conventional physiotherapy, } \\
\text { balneotherapy may be effective in the } \\
\text { treatment of patients with CLBP }\end{array}$ \\
\hline $\begin{array}{c}\text { [Spa therapy in } \\
\text { rheumatology. } \\
\text { Indications based on } \\
\text { the clinical } \\
\text { guidelines of the } \\
\text { French National } \\
\text { Authority for health } \\
\text { and the European } \\
\text { League Against } \\
\text { Rheumatism, and the } \\
\text { results of } 19 \\
\text { randomized clinical } \\
\text { trials] (30) }\end{array}$ & $\begin{array}{l}\text { Françon, A., } \\
\text { Forestier, R. }\end{array}$ & 2009 & $\begin{array}{l}19 \text { randomized controlled } \\
\text { trials that comprised a } \\
\text { statistical comparison of } \\
\text { between-group outcomes }\end{array}$ & $\begin{array}{l}16 \text { studies indicated a persistent } \\
\text { improvement (at least } 12 \text { weeks) in pain, } \\
\text { analgesic and non-steroidal } \\
\text { antiinflammatory drug consumption, } \\
\text { functional capacity and/or quality of life } \\
\text { in CLBP. Spa therapy, or hot-water } \\
\text { balneology, appears to be indicated for } \\
\text { CLBP, stabilized rheumatoid arthritis, } \\
\text { ankylosing spondylitis and fibromyalgia. }\end{array}$ \\
\hline $\begin{array}{l}\text { Effectiveness of } \\
\text { aquatic exercise and } \\
\text { balneotherapy: a } \\
\text { summary of } \\
\text { systematic reviews } \\
\text { based on randomized } \\
\text { controlled trials of } \\
\text { water immersion } \\
\text { therapies (31) }\end{array}$ & $\begin{array}{l}\text { Kamioka, H., } \\
\text { Tsutani, K., } \\
\text { Okuizumi, H., } \\
\text { Mutoh, Y., Ohta, } \\
\text { M., Handa, S., } \\
\text { Okada, S., } \\
\text { Kitayuguch, J., } \\
\text { Kamada, M., } \\
\text { Shiozawa, N., } \\
\text { Honda, T. }\end{array}$ & 2010 & $\begin{array}{l}\text { Systematic reviews based on } \\
\text { randomized clinical trials that } \\
\text { included at least } 1 \text { treatment } \\
\text { group that received aquatic } \\
\text { exercise or balneotherapy. } \\
\text { Articles published from the } \\
\text { year } 1990 \text { to August } 17,2008\end{array}$ & $\begin{array}{l}\text { Aquatic exercise had a small but } \\
\text { statistically significant short-term effect } \\
\text { on locomotor diseases. However, the } \\
\text { long-term effectiveness of balneotherapy } \\
\text { in curing disease or improving health } \\
\text { remains unclear }\end{array}$ \\
\hline $\begin{array}{l}\text { The therapeutic } \\
\text { effect of } \\
\text { balneotherapy: } \\
\text { evaluation of the } \\
\text { evidence from } \\
\text { randomised } \\
\text { controlled trials (32) }\end{array}$ & $\begin{array}{l}\text { Falagas, ME., } \\
\text { Zarkadoulia, E., } \\
\text { Rafailidis, PI. }\end{array}$ & 2009 & $\begin{array}{l}3 \text { randomized controlled trials, } \\
\text { examining the clinical effect of } \\
\text { balneotherapy in CLBP }\end{array}$ & $\begin{array}{l}\text { The available data suggest that } \\
\text { balneotherapy may be truly associated } \\
\text { with improvement in several } \\
\text { rheumatological diseases. However, } \\
\text { existing research is not sufficiently } \\
\text { strong to draw firm conclusions }\end{array}$ \\
\hline
\end{tabular}




\section{Conclusions}

1. Balneotherapy could be beneficial treating patients suffering from low back pain, but there is still not enough quality scientific evidence.

2. Well-designed studies are necessary to provide evidence to balneotherapy treatments.

\section{References}

1. D. Hoy, P. Brooks, F. Blyth, R. Buchbinder. The Epidemiology of low back pain. Best Practice \& Research Clinical Rheumatology. 2010; 24(6): 769-781.

2. Dalke Meucci, R., Gastal Fassa, A., Muller Xavier Faria, N. Prevalence of chronic low back pain: systematic review. Revista de Saúde Pública. 2015; 49(1): 73.

3. Delitto, A., George, SZ., Van Dillen, LR., Whitman, JM., Sowa, G., Shekelle, P., Denninger, TR., Godges, JJ.; Orthopaedic Section of the American Physical Therapy Association. Low back pain. The Journal of Orthopaedic and Sports Physical Therapy. 2012; 42(4): A1-57.

4. Yang, H., Haldeman, S., Lu, ML., Baker, D. Low Back Pain Prevalence and Related Workplace Psychosocial Risk Factors: A Study Using Data From the 2010 National Health Interview Survey. Journal of Manipulative and Physiological Therapeutics. 2016; 39(7): 459472.

5. Campos-Fumero, A., Delclos, George L., Douphrate, David I., Felknor, Sarah A., VargasPrada, S., Serra, C., Coggon, D., Gimeno Ruiz de Porras, D. Low back pain among office workers in three Spanish speaking-countries: findings from the CUPID study. Injury Prevention: Journal of the International Society for Child and Adolescent Injury Prevention. 2017; 23(3): 158164.

6. Ikeda, T., Sugiyama, K., Aida, J., Suboya, T., Watabiki, N., Kodo, K., Osaka, K. Socioeconomic inequalities in low back pain among older people: the JAGES cross-sectional study. International Journal for Equality in Health. 2019; 18(1): 15.

7. Riskowski, JL. Associations of socioeconomic position and pain prevalence in the United States: findings from the National Health and nutrition examination survey. Pain Medicine. 2014; 15(9): 1508-1521.

8. Ministerio de Trabajo, Migraciones y Seguridad Social, Gobierno de España (2011). VII Encuesta Nacional de Condiciones del Trabajo. From http://www.oect.es/portal/site/Observatorio/

9. Murase, K., Tabara, Y., Ito, H., Kobayashi, M., Takahashi, Y., Setoh, K., Kawaguchi, T., Muro, S., Kadotani, H., Kosugi, S., Sekine, A., Yamada, R., Nakayama, T., Mishima, M., Matsuda, S., Matsuda, F., Chin, K. Knee Pain and Low Back Pain Additively Disturb Sleep in the General Population: A Cross- Sectional Analysis of the Nagahama Study. PLoS ONE. 2015; 10(10): e0140058.

10. Vos, T., Allen, C., Arora, M., Barber, RM., Brown, A., Carter, A., et al. Global regional, and national incidence, prevalence and years lived with dissability for 310 diseases and injuries, 1990-2015: a systematic analysis for the global burden of disease study 2015. Lancet. 2016; 388(10053): 1545-1602.

11. Haldeman, S., Kopansky-Giles, D., Hurwitz, EL., et al. Advancements in the management of spine disorders. Best Practice \& Research. Clinical Reumathology. 2012; 26(2): 263-280.

12. Freburger, JK., Holmes, GM., Agans, RP., et al. The rising prevalence of chronic low back pain. Archives of International Medicine. 2009; 169(3): 251-258.

13. Maher, C., Underwood, M., Buchbinder, R. Nonspecific low bakc pain. Lancet. 2017; 389(10070): 736-747.

14. Qaseem, A., Wilt, TJ., McLean, RM., Forciea, MA., for the Clinical Guidelines Committee of the American College of Physicians. Noninvasive Treatments for Acute, Subacute, and Chronic Low Back Pain: A Clinical Practice Guideline From the American College of Physicians. Annals of Internal Medicine. 2017; 166(7): 514-530.

15. Huang, A., Seité, S., Adar, T. The use of balneotherapy in dermatology. Clinics in dermatology. 2018; 36(3): 363-368.

16. Matsumoto, S. Evaluation of the role of balneotherapy in rehabilitation medicine. Journal of Nippon Medical School. 2018; 85(4): 196203. 
17. Fraioli, A., Mennuni, G., Fontana, M., Nocchi, S., Ceccarelli, F., Perricone, C., Serio, A. Efficacy of Spa Therapy, Mud-Pack Therapy, Balneotherapy, and Mud-Bath Therapy in the Management of Knee Osteoarthritis. A Systematic Review. BioMed Research International. 2018; 2018(1): 1042576.

18. Abu-Shakra, M., Mayer, A., Friger, M., Harari, M. Dead Sea mud packs for chronic low back pain. The Israel Medical Association Journal. 2014; 16(9): 574-577.

19. Kulisch, A., Bender, T., Németh, A., Szekeres, L. Effect of thermal water and adjunctive electrotherapy on chronic low back pain: a double-blind, randomized, follow-up study. Journal of rehabilitation medicine. 2009; 41(1): 73-79.

20. Roques, CF., Queneau, P. [SPA therapy for pain of patients with chronic low back pain, knee osteo-arthritis and fibromyalgia]. Bulletin de l'Academie Nationale de Medecine. 2016; 200(3): 575-586.

21. Onat, ŞŞ., Taşoğlu, Ö., Güneri, FD., Özişler, Z., Safer, VB., Özgirgin, N. The effectiveness of balneotherapy in chronic low back pain. Clinical Rheumathology. 2014; 33(10): 1509-1515.

22. Gáti, T., Tefner, IK., Kovács, L., Hodosi, K., Bender, T. The effects of the calciummagnesium-bicarbonate content in thermal mineral water on chronic low back pain: a randomized, controlled follow-up study. International Journal of Biometeorology. 2018; 62(5): 897-905.

23. Morer, C., Roques, CF., Françon, A., Forestier, R., Maraver, F. The role of mineral elements and other chemical compounds used in balneology: data from double-blind randomized clinical trials. International Journal of Biometeorology. 2017; 61(12): 2159-2173.

24. Nemcić, T., Budisin, V., Vrabec-Matković, D., Grazio, S. Comparison of the effects of landbased and water-based therapeutic exercises on the range of motion and physical disability in patients with chronic low-back pain: singleblinded randomized study. Acta Clinica Croatica. 2013; 52(3): 321-327.

25. Bender, T., Bálint, G., Prohászka, Z., Géher, P., Tefner, IK. Evidence-based hydro- and balneotherapy in Hungary--a systematic review and meta-analysis. International Journal of Biometeorology. 2014; 58(3): 311-323.

26. Verhagen, AP., Cardoso, JR., Bierma-Zeinstra, SM. Aquatic exercise \& balneotherapy in musculoskeletal conditions. Best Practice \& Research. Clinical Rheumatology. 2012; 26(3): 335-343.

27. Kesiktas, N., Karakas, S., Gun, K., Gun, N., Murat, S., Uludag, M. Balneotherapy for chronic low back pain: a randomized, controlled study. Rheumatology International. 2012; 32(10): 3193-3199.

28. Tefner, IK., Németh, A., Lászlófi, A., Kis, T., Gyetvai, G., Bender, T. The effect of spa therapy in chronic low back pain: a randomized controlled, single-blind, follow-up study. Rheumatology International. 2012; 32(10): 3163-3169.

29. Dogan, M., Sahin, O., Elden, H., Hayta, E., Kaptanoglu, E. Additional therapeutic effect of balneotherapy in low back pain. Southern Medical Journal. 2011; 104(8): 574-578.

30. Françon, A., Forestier, R. [Spa therapy in rheumatology. Indications based on the clinical guidelines of the French National Authority for health and the European League Against Rheumatism, and the results of 19 randomized clinical trials]. Bulletin de l'Academie Nationale de Medecine. 2009; 193(6): 1345-1356.

31. Kamioka, H., Tsutani, K., Okuizumi, H., Mutoh, Y., Ohta, M., Handa, S., Okada, S., Kitayuguchi, J., Kamada, M., Shiozawa, N., Honda, T. Effectiveness of aquatic exercise and balneotherapy: a summary of systematic reviews based on randomized controlled trials of water immersion therapies. Journal of epidemiology. 2010; 20(1): 2-12.

32. Falagas, ME., Zarkadoulia, E., Rafailidis, PI. The therapeutic effect of balneotherapy: evaluation of the evidence from randomised controlled trials. International Journal of Clinic Practice. 2009; 63(7): 1068-1084. 